\title{
Participatory Design for Accessible Evacuation Centre for Flood Victims in Kelantan
}

\author{
Wan Mohamad Amin W Seman ${ }^{1}$, Asiah Abdul Rahim²), Izawati Tukiman ${ }^{3)}$ \\ ${ }^{1,2)}$ Department of Architecture, Kulliyyah of Architecture \& Environmental Design, International Islamic \\ University Malaysia, Kuala Lumpur, Malaysia \\ ${ }^{3)}$ Department of Landscape Architecture, Kulliyyah of Architecture \& Environmental Design, International \\ Islamic University Malaysia, Kuala Lumpur, Malaysia
}

\author{
Manuscript received: \\ January 12, 2021 \\ Manuscript revised: \\ February 28, 2021 \\ Manuscript accepted: \\ February 28, 2021 \\ Date of publication: \\ February 28, 2021. \\ Corresponding author: \\ Wan Mohamad Amin Bin W Seman \\ wamin92@gmail.com
}

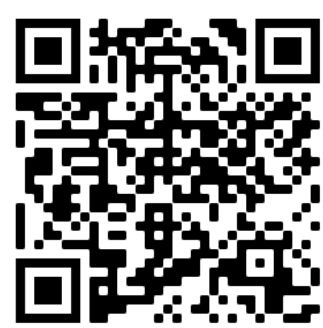

\begin{abstract}
Malaysia has been experienced with many natural disasters such as flood, landslide, earthquake and drought, which resulted in damaging the properties and causing casualties especially during the biggest flooding affected over 36,128 families was in 2014 at East Coast of Malaysia mainly in Kelantan. Public buildings such as schools, religious buildings, including mosques or community halls, have been used as evacuation centres in Malaysia every year. Many studies identified many evacuees were facing many problems, particularly in terms of physical facilities, such as providing improper assistance in terms of facilities, privacy, and many others. This paper objectives are firstly, to review the requirements of the physical facilities for evacuation centre, secondly to assess the components of the physical facilities for evacuation centre and finally to propose the criteria of physical facilities for evacuation centre. A qualitative approach was adopted, and data were collected through observation, interview and secondary data through literature analysis. Three case studies in Kelantan were chosen based on three categories which are small capacity (Veteriner office, Kuala Krai), medium-capacity (Sekolah Menengah Kebangsaan Keroh, Kuala Krai) and big capacity (Sekolah Menengah Kebangsaan Agama Lati, Pasir Mas). The data were analysed to assess the physical facilities provided in the evacuation centre to facilitate the flood victims. The benefit of this research is to give awareness to flood victim for future disaster through technology, management, physical and mental. Thus, evacuation centre is important to create comfortable, privacy and rehabilitated environment to serve the flood victims physically and mentally.
\end{abstract}

Keywords: accessible, disaster, evacuation centre, flood victims, physical facilities.

\section{INTRODUCTION}

In December 2014, Malaysia was stunned by the news of the floods taking place on the East Coast of Malaysia, especially in Kelantan. East Coast of Malaysia, particularly in Kelantan were facing the massive floods every year due to our monsoon season, and flood that occurred in 2014 was the worst, where the water levels in most of the floods in the region were superseded by the floods of the last big flood of 1967 (National Security Council (NSC) via Datuk Mohamed Thajudeen Abdul Wahad, 2015).

Copyright (C) 2021 The Author(s).

(i) (2) This is an Open Access article distributed under the terms of the Creative Commons Attribution-ShareAlike 4.0 International (https://creativecommons.org/licenses/by-sa/4.0/) 


\section{A. Flood in Malaysia}

Floods typically occur unpredictably but based on the previous experience, we can sense the early sign of flooding that happens particularly when heavy rainfall persists. The preparedness for early flooding must be taken to face potential flooding in relation to past flooding that occurs. According to Lawal Billa, et. al. (2006), the previous disaster incident should be studied to expose the region's vulnerabilities and insufficiencies in disaster management and preparedness. In addition, emergency management or disaster management involving preparedness, response and recovery is one of the disciplines in dealing with and avoiding both natural and manmade disasters, while at the same time reducing disaster impacts (Free Farlex Diktionary, 2015). Disaster management can also be one of the places involving disaster training, studying, and predicting the threat, as well as rescue activities. On the other hand, the community and administration preparedness must be increased to reduce the risk of natural disaster, such as flood, which we are unable protect (Center for Science and Environment, 1996). According to Lawal Billa, et. al. (2006), they highlighted that;

"in the phase of disaster preparedness, it is a tool for planning evacuation routes, designing emergency centers and integrating satellite data with other relevant data in the design of disaster warning systems".

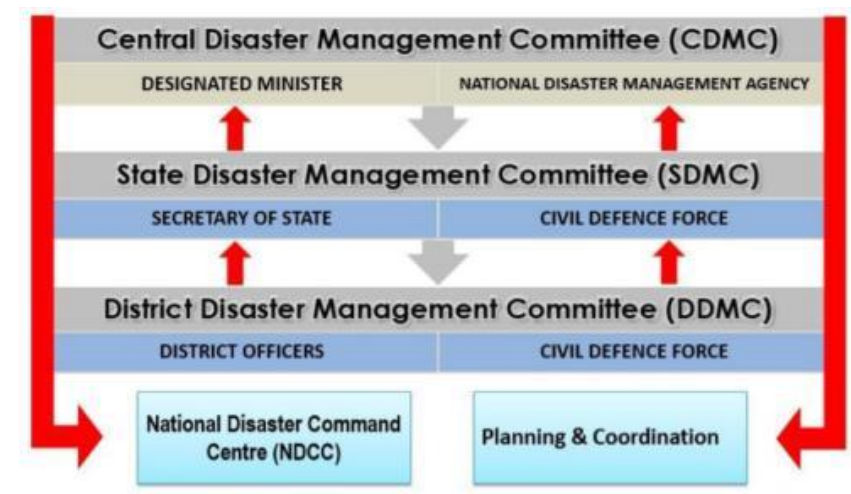

Fig. 1. Disaster management mechanism in Malaysia.

Source: Malaysia Civil Defence Force (2019)

During the monsoon season, the Evacuation Centre would serve as a flood control centre where the at the same time it has been equipped to operate as the victim's evacuation centre (Figure 1). According to Norliza Katuk, et. al. (2009), that an evacuation centre would only operate with the instruction by the district officer (chaiman of district disaster released committee) during emergency. All agencies are responsible and incharged of safe and rescue either in the flood area and at the operation centre. Proper physical planning must be planned to anticipate future impact due to disaster occurrences (Vinod K. SharmaTanu Priya, 2001). A good disaster planning strategy can be achieved through an effective and efficient response to the disaster. According to Norliza Katuk, et. al. (2009). and Ngai Weng Chan (1995) there are 4 types of human reaction to disasters, which are: a) to protect (prevent and modify disasters) b) to accommodate (change human use system to suit disasters) c) to retreat (resettlement, forbid development in disaster zones, migration), and d) not taking any action (Table 1). 
Table 1. Some descriptions on the Management at Evacuation Centre

\begin{tabular}{|c|c|}
\hline Reference & Description \\
\hline $\begin{array}{l}\text { Somasundaram \& } \\
\text { Davies (2014) \& } \\
\text { Queensland } \\
\text { Government, } 2013 \\
\text { in Siti Falindah } \\
\text { Padlee, rt.al } \\
(2018)\end{array}$ & $\begin{array}{l}\text { The evacuation centre is one of the important elements to } \\
\text { have in place whenever a disaster happens. It is a safe place } \\
\text { for the community to assemble (Somasundaram \& Davies } \\
\text { (2014) } \\
\text { Evacuation and the use of evacuation centres, involves the } \\
\text { planned and coordinated movement of persons from an unsafe } \\
\text { or potentially location to a safer location..." (Queensland } \\
\text { Government, 2013). }\end{array}$ \\
\hline $\begin{array}{l}\text { Norliza Katuk, Ku } \\
\text { Ruhana Ku- } \\
\text { Mahamud, Norita } \\
\text { Norwawi \& Safaai } \\
\text { Deris (2009) }\end{array}$ & $\begin{array}{l}\text { A flood operation center (FOC) will be activated by the } \\
\text { district officer when a flood begins. In this case, all } \\
\text { representatives of each agency will be in the flood area and at } \\
\text { the same time other representatives will be in the flood } \\
\text { operation center } \\
\text { A good disaster planning strategy can be achieved through an } \\
\text { effective and efficient response to the disaster }\end{array}$ \\
\hline $\begin{array}{lr}\text { Lawal } & \text { Billa, } \\
\text { Mansor } & \text { Shattri, } \\
\text { Ahmad } & \text { Rodzi } \\
\text { Mahmud \& } & \text { Abdul } \\
\text { Halim } & \text { Ghazali } \\
(2006) & \end{array}$ & $\begin{array}{l}\text { it is critical that disaster management measures are prepared } \\
\text { and implemented when they arise to avoid or minimise their } \\
\text { or other flood impacts }\end{array}$ \\
\hline
\end{tabular}

\section{B. Participatory Design for Evacuation Centre}

Participatory design is a philosophy that uses participative approaches to involve users in the design process. This is an approach that actively involves all stakeholders in the design process to ensure the design meet the needs of target users. Engaging their ideas and incorporating them in later versions of the design. In Malaysia cases, various agencies were involves in the operational of an evacuation centre, such as police, fire and rescue team, arm force and

As a member of the National Disaster Management and Relief Committee, Department of Social Welfare is responsible for the work of aid delivery and recovery of disaster victims. As contained in Directive National Security Council (NSC) No. 20 Social Welfare Department has four (4) main roles and responsibilities are: a) Prepare and maintain evacuation centres. b) Prepare and distribute donations of food, clothing, and other necessities. 23 c) Carry out the registration on the victim for the purpose of recovery of the victims. d) Provide guidance, advice, and counselling to victims.

According to Department of Social Welfare Malaysia (2019), every evacuation centre in Malaysia was managed by a group of local people appointed by District officer. Each evacuation centre was led by one manager who is an officer from Department of Social Welfare District office. Officer can manage more than one evacuation centre.

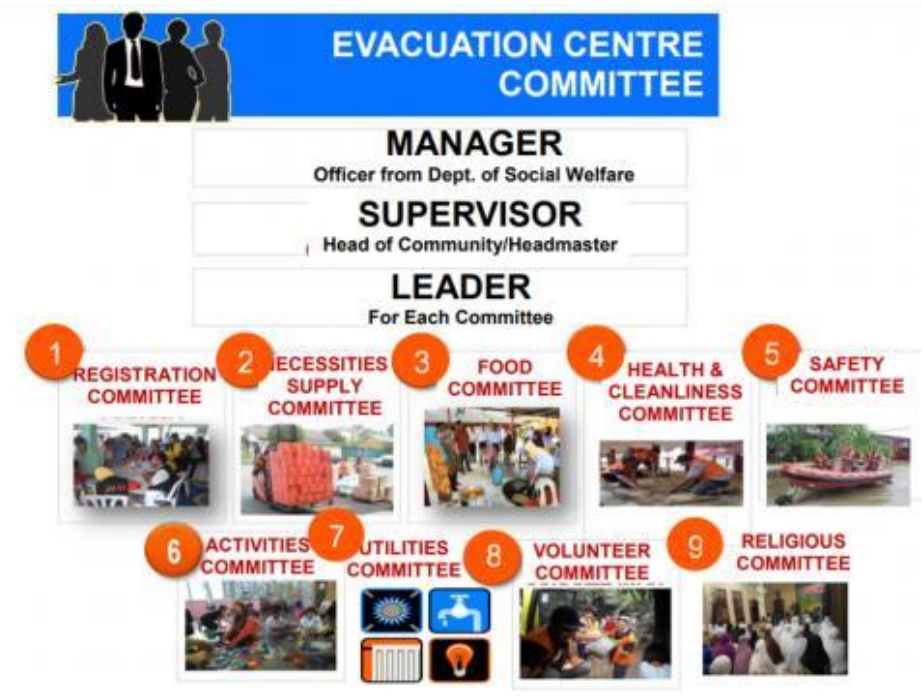

Fig. 2. The organisation chart of evacuation centre in Malaysia Source: Department of Social Welfare (2019) 
The needs to provide the facilities for PwDs are compulsory in every public building, especially at the evacuation centre. According to the Person with Disabilities Act 2008 (Act 685), clause 26 (1), PwDs have the right to use and access to public facilities, services, amenities, and buildings that provided for public on equal basis. Under this clause also mentioned on the public facilities provided must be universal design to facilitate PwDs to use and access on the facilities.

\section{Methodology}

An observation has been conducted, as the purpose of this analysis was not to conduct a test but to provide the sample with a general context. Case studies are to be performed by interviews with the management of centre and observations. Tools include a detailed assessment of the building used as an evacuation centre.

The methods include descriptive observation of the building and inventory analysis of the centre. An inventory review was conducted to examine the specific aspects of the evacuation centre that mainly focuses as victim shelter.

\section{CaSe STUdies}

The case studies were in Kelantan, at the most affected area of the flood. The areas are the most affected area with the largest evacuees due to an unexpected rise of flood in 2014.

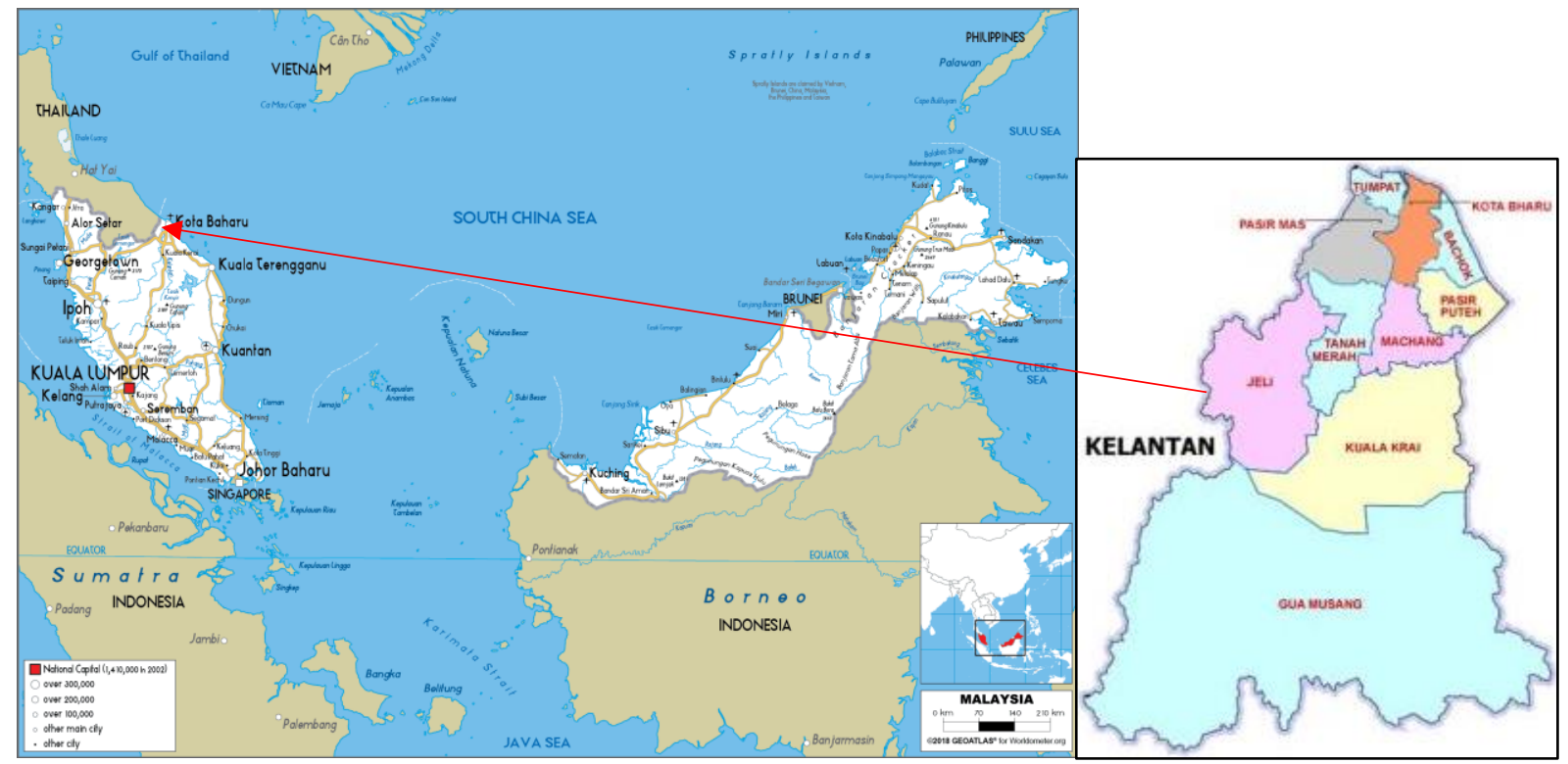

Fig. 3. Map of Kelantan in Malaysia.

\section{A. Case Study 1: Veteriner Office, Guchil, Kuala Krai, Kelantan}

Veteriner Office in Guchil, Kuala Krai, Kelantan was gazetted as one of the Evacution centre to be used by the flood victims surrounding the area of Guchil since 2007. This evacuation centre will cover the victims at the area of Guchil 5 and 7, Kuala Krai, Kelantan (Figure 3). This evacuation centre has 2 blocks of building, a hall that can accommodate between 5-6 small families, 2 toilet and 2 bathrooms. Most of activities such as cooking, and others are done in the hall or lounge area in front of the buildings. The victims were house in an open plan hall areas, and Jabatan Kebajikan Masyarakat (JKM) provided them with temporary compartment for their privacy (Figure 5). 
Participatory design for accessible evacuation centre for flood victims in Kelantan

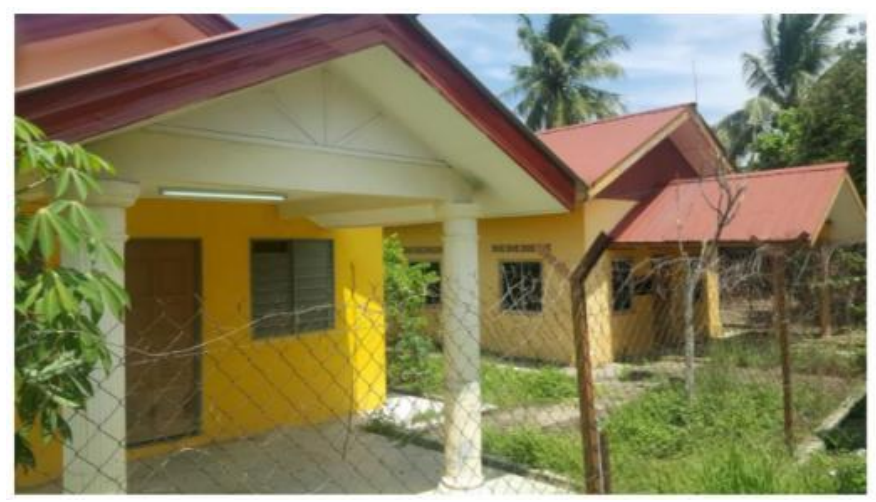

Fig. 4. Two blocks of buildings were prepared that can facilitated around maximum of 50 people only.

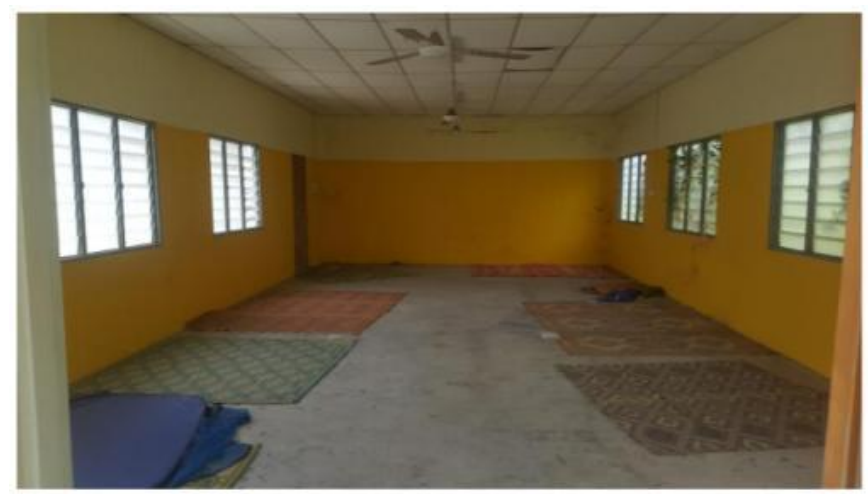

Fig. 5. Hall to accommodate flood victims.

\section{B. Case Study 2: Sekolah Menengah Kebangsaan Keroh, Mengkebang, Kuala Krai, Kelantan}

Sekolah Menengah Kebangsaan Keroh was in mukim Mengkebang, Kuala Krai, Kelantan was gazetted as one of the Evacution centre to be used by the flood victims. This evacuation centre was categorized as medium capacity that can facilitate around 500 people only. During flooded season, this evacuation centre can cover victims of resident from $\mathrm{Kg}$. Keroh (Figure 6). Flood victims were group in the multipurpose classroom and hall that can function as sleeping area. There is a dining hall and one complex toilet area which was built for the use of flood victims.

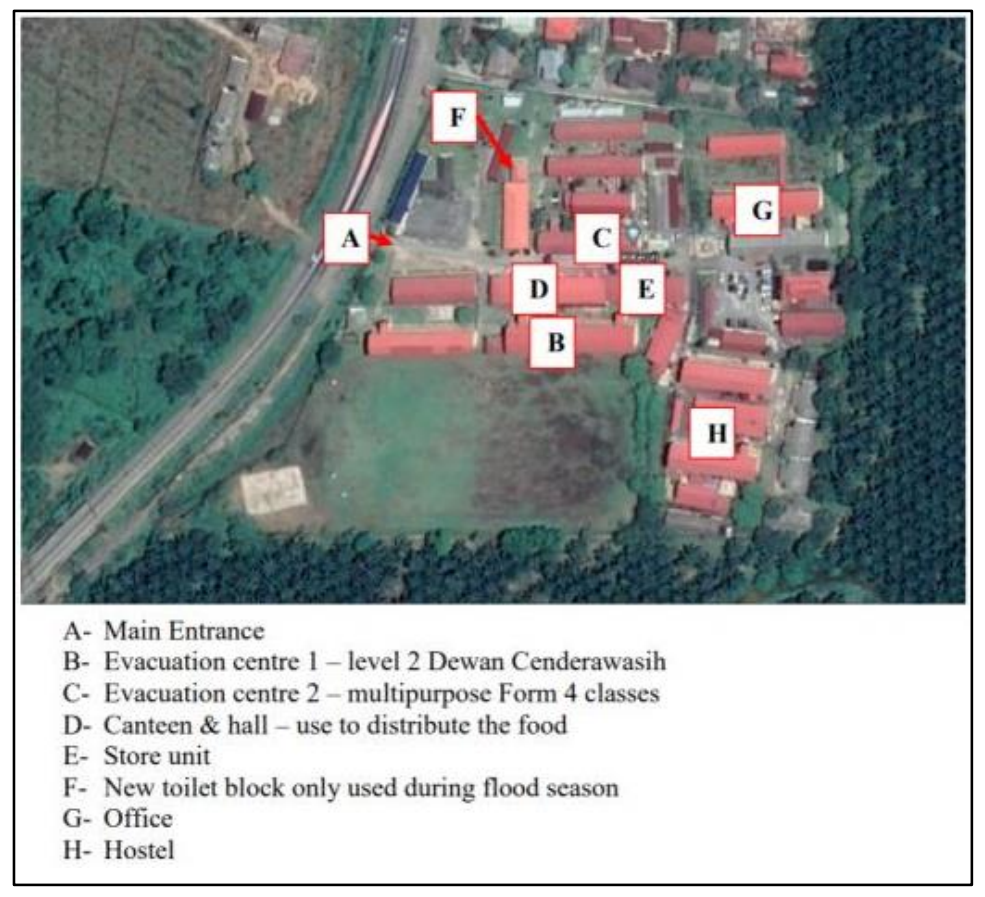

Fig. 6. Master plan of SMK Keroh, Mengkebang, Kuala Krai 


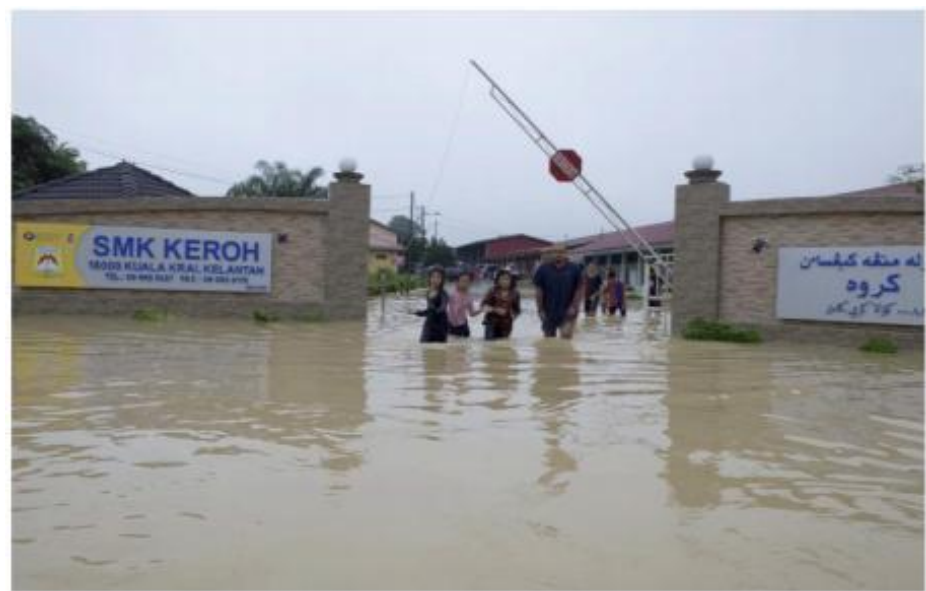

Fig. 7. SMK Keroh was flooded due to the overflow of Sungai Nal in Kampung Keroh in 2014 Source: BH Online (2014)

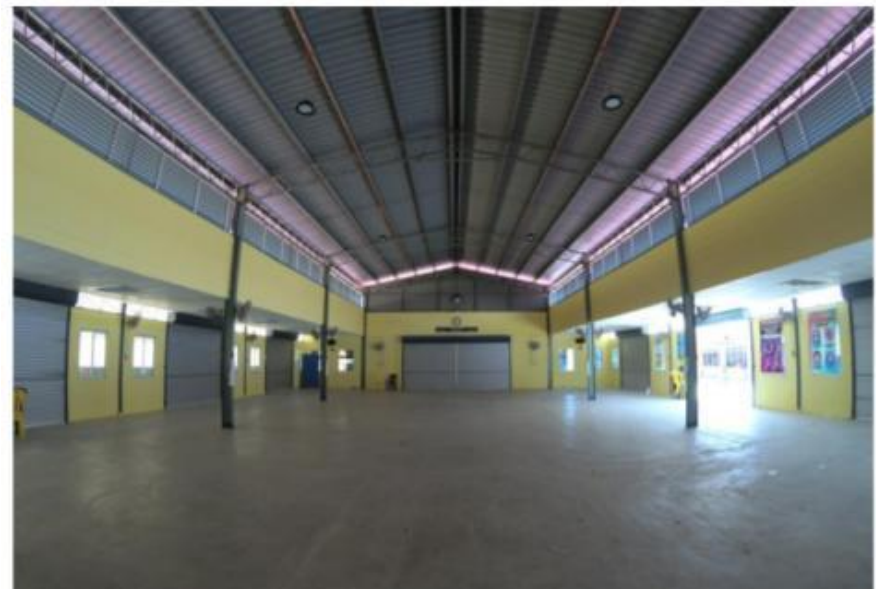

Fig. 8. Hall that used to accommodate flood victims.

\section{Case Study 3: Sekolah Menengah Kebangsaan Agama (SMKA) Lati, Pasir Mas, Kelantan}

Sekolah Menengah Kebangsaan Agama (SMKA) Lati located at Pasir Mas, Kelantan was gazetted as an evacuation centre to be used by the flood victims by Department of Social Welfare. The village involved are the resident from Kg. 61 Banggol Jering, Kg. Banggol Manak, Kg Kepas Apam, Kg Lati, Pondok Lati, Kg Serai Lima, Taman Alia and Taman Sri Mas. The facilities provided are hall, mosque, multipurpose classroom, canteen as dining area and toilet at each block (Figure 8).

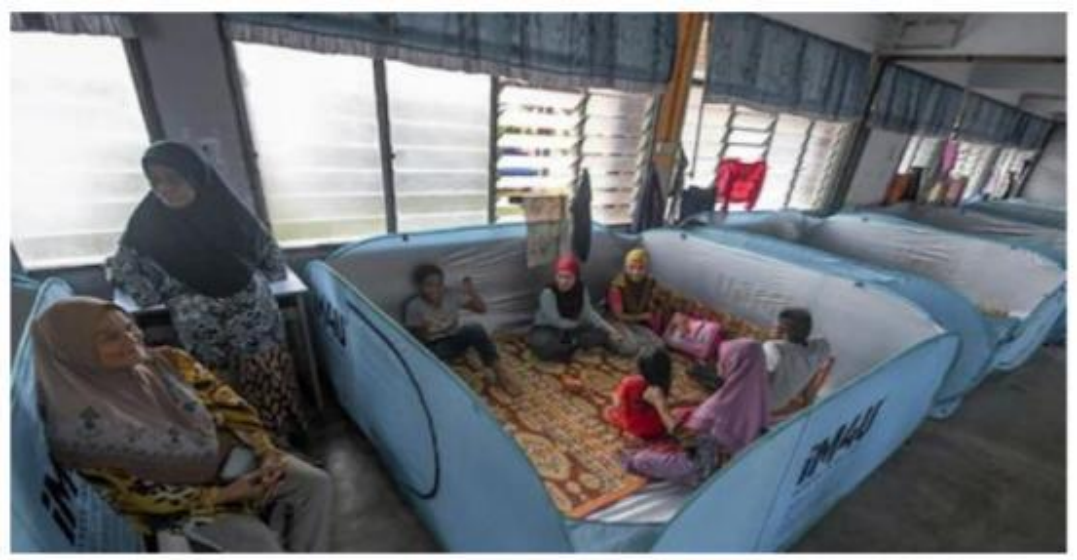

Fig. 9. Tents were provided for each family as sleeping area

Source: Bernama, (2019) 


\section{ANALYSIS AND FINDINGS}

Based on the data collected for all 3 case studies there are three components that has been covered in these studies, and a comparison was put in Table 2. It shows that all case studies do not accessible by Person with Disabilities (PwDs). However, schools are better evacuation centre as it has better facilities as compared to community centre.

Table 2. Comparison between 3 case studies

\begin{tabular}{|c|c|c|c|}
\hline Facilities & $\begin{array}{l}\text { Case Study 1: } \\
\text { Veteriner Office } \\
\end{array}$ & $\begin{array}{l}\text { Case Study 2: SMK } \\
\text { Keroh }\end{array}$ & $\begin{array}{l}\text { Case Study 3: SMKA } \\
\text { Lati }\end{array}$ \\
\hline Type & Community centre & School & School \\
\hline $\begin{array}{l}\text { Hall Size for sleeping } \\
\text { area }\end{array}$ & $\begin{array}{l}\text { Can accommodate } 50 \\
\text { people only }\end{array}$ & $\begin{array}{l}\text { Can accommodate } 500 \\
\text { people only }\end{array}$ & $\begin{array}{l}\text { Can accommodate } 2000 \\
\text { people only }\end{array}$ \\
\hline Toilet & Only 4 cubicle & $\begin{array}{l}\text { There additional toilet } \\
\text { provided only for flood } \\
\text { victims }\end{array}$ & $\begin{array}{l}\text { Use existing school toilet. } \\
\text { No additional toilet for } \\
\text { flood victims }\end{array}$ \\
\hline Dining area & No dining area. & $\begin{array}{l}\text { There are school canteen } \\
\text { can be used as dining area }\end{array}$ & $\begin{array}{l}\text { There are school canteen } \\
\text { can be used as dining area }\end{array}$ \\
\hline Cooking area & $\begin{array}{l}\text { No cooking area. } \\
\text { Need to cook outside } \\
\text { the building }\end{array}$ & $\begin{array}{l}\text { There are school canteen } \\
\text { can be used as cooking } \\
\text { area }\end{array}$ & $\begin{array}{l}\text { There are school canteen } \\
\text { can be used as cooking } \\
\text { area }\end{array}$ \\
\hline Store unit & No store unit & $\begin{array}{l}\text { One store room was used } \\
\text { as to store the supply. } \\
\text { Limited space }\end{array}$ & $\begin{array}{l}\text { One store room was used } \\
\text { as to store the supply. } \\
\text { Limited space }\end{array}$ \\
\hline $\begin{array}{l}\text { Accessible for PwDs, } \\
\text { elderly or pregnant } \\
\text { women }\end{array}$ & No accessible & No accessible & No accessible \\
\hline Praying area & No praying area & $\begin{array}{l}\text { There are musolla that can } \\
\text { be used for praying area }\end{array}$ & $\begin{array}{l}\text { There are musolla that can } \\
\text { be used for praying area }\end{array}$ \\
\hline $\begin{array}{l}\text { Area for social } \\
\text { activities }\end{array}$ & $\begin{array}{l}\text { Sleeping area were } \\
\text { used to organise any } \\
\text { activities }\end{array}$ & Provided, use existing hall & Provided, use existing hall \\
\hline $\begin{array}{l}\text { Medical treatment } \\
\text { area }\end{array}$ & No & No & No \\
\hline
\end{tabular}

Referring to the design consideration for disaster relief centre, it shows that all centres do not consider climatic conditions into design consideration. As some are using existing buildings, it was observed that all centre is exposed to the direct sunlight and heavy rain. On the other hand, all victims do not have privacy, they are visible to culture and social issues such as loitering, snoop and other social issues. Therefore, it can lead to different level of criminals such as rape, steal and others. The social problems that might happened at the evacuation centre needs to be taken care and solution need to be identify for their safety, welfare, and comfort. On the other hand, there is no proper storage to install personal items or documents to secure victims important belongings. There is a need for future planning to improve the school as it will continuously use as evacuation centre every year especially during monsoon seasons. On top of that, accessibility are the most crucial attributes that need to be improved. All level of ages being relocate to the evacuation centre including the aged, person with disabilities, children and others, thus, they need proper facilities that can ease their movements in the buildings. Without these facilities, they might feel stress due to limitation of movement.

\section{CONClusion}

The evacuation centre plays a significant role in safe and rescue process for the victims of flooding. The importance of providing flexible and comfortable places for flood victims was also highlighted, as most of them were disaster traumatising and needed comfort, safety, and privacy as a way of rehabilitation during, before and after disaster. The component of the evacuation centre must 
also be considering the comfort of the victims and facilitating their welfare throughout this study. The level of preparedness for the evacuation centre must also be reviewed annually so that they are prepared for future floods.

\section{ACKNOWLEDGEMENT}

We would like to thanks to all that contributed in this research such as, interviewees at Evacuation Centre in Kuala Krai and Pasir Mas, Kelantan and officers from organisations, which are Department of Social Welfare, National Disaster Management Agency, whom kindly spend spare some time and providing great input for the data collection.

\section{REFERENCES}

Abu-Gazzeh, T. (1993). Privacy as the basis of architectural planning in the Islamic culture of Saudi Arabia. Architectural \& Behavioural Journal, 11(30), 269-288.

Asiah, A. R., Ismawi, Z., Mohd Ramzi, M. H., Izawati, T., \& Che Zulkhairi, A. (2015). User perception of mobile homes for shelter relief centre as a respond for flood disaster preparedness. (n.d.): Kementerian Pengajian Tinggi.

Azlee, A. (2015). Worst flood in Kelantan, confirms National Security Council (NSC). Retrieved from Malaymail at https://www.malaymail.com/s/813959/worstfloods-in-kelantan-confirms-nsc

Bologna, R. (2010). Planning and designing post disaster transitional housing: The case of the Abruzzo (Italy) earthquake. Proceedings TG63 - Special Track 18th CIB World Building Congress,

Balford, UK. Davis, I. R. (1978). Part one: Emergency shelter. The Role of Technology in International Disaster Assistance: Proceedings of the Committee on International Disaster Assistance Workshop. March 1977, Washington, DC.

Asiah Abdul Rahim \& Wan Mohamad Amin W Seman (2019). Concept of Privacy from Islamic Perspective in Flood Evacuation Centre () 2019 by MIP 266

Marcus, J. S., \& Carter, K. (2007). Comparison of privacy and trust policies in the area of electronic communications. (n.p.): (n.p.).

McInerny, T. (2012). Emergency sheltering in Australia: Considerations beyond the four walls and a roof. Retrieved from https://www.redcross.org.au/getmedia/23ed0b6d-af70-4abb-bdf8d1e32f84d451/Emergency-sheltering-poster.pdf.aspx.

Nik Nor Ronaidi, N. M. (2012). Emergency response planning and implementation (PowerPoint slides). Retrieved from https://www.slideshare.net/NikRonaidi/emergency-response-planning-andimplementation-15685052

Said, M. Z, Gapor, S. A., Samian, M. N, \& Aziz, A. M. A, (2013). Konflik di pusat pemindahan banjir: Kajian kes di Daerah Padang Terap, Kedah. Malaysia Journal of Society and Space, 9(1), 61-69.

Siti Falindah, P., \& Nik Nadrul Hisham, N. R. (2015). The perceived quality and satisfaction with services at evacuation centres: The case of Kemaman Evacuation Centre. South East Asia Journal of Contemporary Business, Economics and Law, 8(2), 21-29.

Somasundaram, T., \& Davies, J. B. (2014). Collaboration to improve evacuation centre operations in Queensland. International Journal of Disaster Resilience in the Built Environment, 5(3), 305-317. The Malaysian Insider (2014) worsenbernama

Victoria Department of Human Services (2013). Emergency relief handbook: A planning guide. Melbourne: Author 